\title{
An environmentally friendly soil improvement technology for sand and dust storms control
}

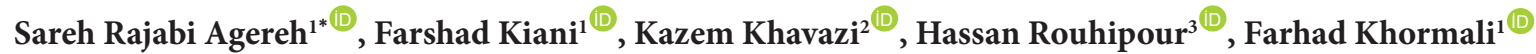 \\ ${ }^{1}$ Department of Soil Sciences, Soil and Water Engineering School, Gorgan University of Agricultural Sciences and Natural Resources, \\ Gorgan, Iran \\ ${ }^{2}$ Department of Biology, National Institute of Soil and Water Research, Karaj, Iran \\ ${ }^{3}$ Department of Biology, Forestry and Rangeland Research Institute, Tehran, Iran
}

\begin{abstract}
Background: Dust storms occur when unchecked, strong, or turbulent winds combine with exposed loose and dried soil surfaces. Sand and dust storms have a significant impact on society, economy, and environment at local, regional, and global levels. The environmental and health hazards of such storms cannot be permanently reduced, however, by taking appropriate measures, its impact can be reduced. The present study aimed to investigate the effects of microbial precipitation of calcium carbonate $(\mathrm{CaCO} 3)$ as a biocompatible agent on soil stabilization and control of dust storms using ureaseproducing bacteria (UPB) as a biological improvement technique, which were isolated, identified, sprayed on the soil surface.

Methods: For this purpose, the erosion of bio-cemented soil samples was investigated experimentally in a wind tunnel under the condition of wind velocity of 0 to $98 \mathrm{~km} \cdot \mathrm{h}^{-1}$ in two soil types with sandy and silty texture in a completely randomized design with three replicates.

Results: The investigation of the threshold wind velocity of soil particles showed that soil particles began to move at velocity of 8 and $10 \mathrm{~km} \cdot \mathrm{h}^{-1}$ in silty and sandy soils, respectively, but in all biological samples (MICP), particles did not move until the wind speed reached $97 \mathrm{~km} . \mathrm{h}^{-1}$. It was also revealed that the weight loss of all MICP-treated samples at different wind velocities was significantly reduced compared to the control group. Differences in the amount of soil loss among bio-cemented samples and control treatments were even superior at higher velocities, so that at velocities more than $57 \mathrm{~km} . \mathrm{h}^{-1}$, soil losses increased significantly in the control group, while in soils treated with bacteria, soil loss was very low (about $2.5 \mathrm{~kg} \cdot \mathrm{m}^{-2} \cdot \mathrm{h}^{-1}$ ). Comparison of the bacteria used in this study also showed that Bacillus infantis and Paenibacillus $\mathrm{sp}_{3}$ had high efficiency in controlling dust storms.

Conclusion: The formation of abrasion-resistant surface layers on soil samples treated by biocementation showed that cementation by biological methods could be an effective way to stabilize surface particles and control sand and dust storms.

Keywords: Urease, Dust storms, Bio cement, Soil loss flux

Citation: Rajabi Agereh S, Kiani F, Khavazi K, Rouhipour H, Khormali F. An environmentally friendly soil improvement technology for sand and dust storms control. Environmental Health Engineering and Management Journal 2019; 6(1): 63-71. doi: 10.15171/EHEM.2019.07.
\end{abstract}

Article History:

Received: 16 December 2018 Accepted: 25 February 2019 ePublished: 13 March 2019

\section{Introduction}

Soil erosion is an important land degradation process that effects on the soil productivity. It has been estimated that about 75 billion tons of soil are removed each year by water and wind erosion (1).

Wind erosion is known as a major environmental process in arid and semi-arid regions of the world because it causes land degradation and desertification (2), particularly in the world's dry lands (3).

Sand and dust storms have considerable negative impacts on the infrastructure, economy, and environment, and they have become a serious threat to human health because of their role in the formation of suspended particulate matter and air pollution (4). This phenomenon is dominant in the regions with a sparse vegetation coverage due to low precipitation ( $<300 \mathrm{~mm}$ annually), high evapotranspiration, and loose, finely and smooth soil surface with strong winds (5).

Due to the effects of many factors including climate conditions (e.g. precipitation, wind, and temperature), soil properties (e.g. soil texture, composition, and aggregation), land-surface characteristics (e.g. topography, moisture, aerodynamic roughness length, and vegetation coverage) and land-use practice (e.g. farming, mining, and grazing), wind erosion is a complex process (6).

There are many chemical (7-9), mechanical, and 
biological $(10,11)$ technologies to control and prevent wind dispersion of dust, wind erosion of soil, and desertification (12). Traditional prevention techniques use chemical stabilizers and cementing agents, however, not only their application is expensive, but also due to the solubility of the reagents in water and their dispersion in the environment with runoff, they may have also negative effects on plants (9), quality of surface and ground waters, and public health (12). Also, agronomic measures are one of the conventional way for preventing soil erosion using living vegetation or the residues from harvested crops to protect soil from wind erosion, but it is limited by agricultural conditions (12).

Application of bio-mediated cementation of the soil particles can be an alternative way for the dust suppression with chemical reagents (13-15). Microbial geotechnology is an emerging branch of geotechnical engineering that deals with the applications of biological methods to geotechnical engineering problems (13). The most popular technology of biocementation is a process to produce binding material (biocement) based on microbial-induced carbonate precipitation (MICP) mechanism that can be applied in many fields such as construction, petroleum, erosion control, and environment (12).

In addition, the hydrolysis of urea is a chemical reaction, where the urease enzyme produced in situ by ureaseproducing bacteria (UPB) or supplied directly into the soil, decomposes urea $\left(\mathrm{CO}\left(\mathrm{NH}_{2}\right)_{2}\right)$, and the ammonium $\left(\mathrm{NH}_{4}^{+}\right)$released from urea hydrolysis results in local $\mathrm{pH}$ increase and in the presence of calcium ions, commences the precipitation of calcium carbonate $(\mathrm{CaCO} 3)$ in the soil. The high $\mathrm{pH}$ favors bacterial activity. Calcite is precipitated through the combination of carbonate ions $\left(\mathrm{CO}_{3}{ }^{2-}\right)$ from the hydrolysis of urea and the calcium ion $\left(\mathrm{Ca}^{2+}\right)$ supplied in as calcium chloride (16).

$\mathrm{CO}\left(\mathrm{NH}_{2}\right)_{2}+2 \mathrm{H}_{2} \mathrm{O}+\mathrm{UPB} \rightarrow 2 \mathrm{NH}_{4}^{+}+\mathrm{CO}_{3}^{2-}$

$\mathrm{Ca}^{2+}+\mathrm{CO}_{3}^{2-} \rightarrow \mathrm{CaCO}_{3}(1)$

Maleki et al evaluated the efficiency of MICP for loose sand dune stabilization and reported that the effect of biological treatment on wind erosion control at the higher velocities was even superior, so that at the velocity of 55 $\mathrm{km} \cdot \mathrm{h}^{-1}$, erosion rate of MICP-treated samples was 2.13 against $240 \mathrm{~kg} \cdot \mathrm{m}^{-2} \mathrm{~h}^{-1}$ (17). Gomez et al focused on a field-scale, surficial application of MICP experiment to improve the erosion resistance of loose sand sediments and provide surface stabilization for dust control. They concluded that the most improved test plot received the lowest concentrations of urea and calcium chloride and formed a stiff crust measuring $2.5 \mathrm{~cm}$ thick, indicating an increased resistance to erosion (18). Many researchers have reported that microbial mineral precipitation method is more effective in sandy soils compared to silts or clay (19). The aim of the present study was to isolate and identify UPB strains and compare their ability for bio- cementation of silty soils.

\section{Materials and Methods}

Isolation and identification of the isolated UPB

For this study, 10 soil samples were collected from Golestan province, Iran, from $0-5 \mathrm{~cm}$ depth using sterile tools and placed into sterile containers. All samples were stored on ice for immediate transport to the lab.

For enrichment and isolation of ureolytic bacteria of the soils, $50-\mathrm{mL}$ sterile syringe barrels (syringes without plungers) were used as soil columns. Each column was filled to the $20 \mathrm{cc}$ line. A tube was connected to the bottom of each syringe barrel and clamped closed to retain the solutions within the soil matrix, and the columns remained sealed on the bottom and were covered with aluminum foil to exclude light.

Soil in columns were treated once with an enrichment solution containing $333 \mathrm{mM}$ urea, $170 \mathrm{mM}$ sodium acetate, $0.5 \mathrm{~g} / \mathrm{L}$ Bacto yeast extract, and $0.5 \%$ (by volume) Grandma's molasses.

After three days, the columns were drained and treated three times, every other day, with a solution containing $170 \mathrm{mM}$ sodium acetate, $0.5 \mathrm{~g} / \mathrm{L}$ Bacto yeast extract, and $333 \mathrm{mM}$ urea.

After 48 hours of the third treatment, about $1 \mathrm{ml}$ of the effluent was collected from each column into sterile microcentrifuge tubes. Bacteria were aseptically collected from the effluent by centrifugation.

The pellet was washed with cold and sterile phosphatebuffered saline (PBS) (8.0 g/L NaCl, 0.2 g/L KCL, 1.44 $\mathrm{g} / \mathrm{L} \mathrm{NaHPO}_{4}$, and $\left.0.24 \mathrm{~g} / \mathrm{L} \mathrm{KH}_{2} \mathrm{PO} 4\right)$ three times and centrifuged. The final pellet was suspended in $5 \mathrm{ml}$ of sterile PBS. The bacterial suspension was serially diluted and plated on the modified urea agar $(5 \mathrm{~g} / \mathrm{L} \mathrm{NaCl}, 2 \mathrm{~g} / \mathrm{L}$ $\mathrm{KH}_{2} \mathrm{PO}_{4}, 1 \mathrm{~g} / \mathrm{L}$ glucose, $0.012 \mathrm{~g} / \mathrm{L}$ phenol red, $0.2 \mathrm{~g} / \mathrm{L}$ peptone, $20 \mathrm{~g} / \mathrm{L}$ urea, $15 \mathrm{~g} / \mathrm{L}$ agar, and $\mathrm{pH}$ 6.8).

All solutions were added by pipetting the solution into the top of each tube and were allowed to gravity feed through the soil, then, the columns were sealed with approximately 5 cc's of the pooled solution on top of the soil.

The plates were incubated at $22^{\circ} \mathrm{C}$ (darkness). Colonies that turned the agar pink or red ( $\mathrm{pH}$ increase) were considered candidates for this study. Isolates that could hydrolyze urea were picked and streaked for isolation onto urea agar (20).

\section{Measurement of urease activity}

Urease activity was determined using measurement of electric conductivity in the experiments. The amount of ammonium produced from a $1 \mathrm{M}$ solution of urea/min was defined as urease activity. An aliquot of 1 or $10 \mathrm{~mL}$ of bacterial suspension was added to $100 \mathrm{~mL}$ of $1 \mathrm{M}$ urea solution. Using an electrical conductivity (EC) meter, the concentration of ammonium produced from urea was determined, indicating a linear correlation between the difference of molar concentrations of $\mathrm{NH}_{4}^{+}(\Delta C)$ and the 
changes of EC of solutions $(\Delta S)$ in $\mathrm{mS} / \mathrm{cm}$ : (12).

$(\Delta \mathrm{C})=(\Delta \mathrm{S}) / 0.063(2)$

Evaluation of the isolates tolerance to drought

Using Polyethylene glycol 6000 (PEG 6000) in Nutrient Broth Media with different concentrations, the drought tolerance of the isolates was examined (21). The isolates were inoculated in sterile condition on a rotator shaker for 72 hours at $27^{\circ} \mathrm{C}$, and then, their optical density (OD) at $600 \mathrm{~nm}$ was measured (Table 1).

\section{The experimental setup}

To conduct this research, undisturbed soil samples with silty and sandy texture were collected from a wind erosionaffected area in the northeast of Iran, Golestan province (latitude of $55^{\circ} 27^{\prime} \mathrm{N}$ longitude of $37^{\circ} 55^{\prime} \mathrm{E}$ and latitude of $54^{\circ} 25^{\prime} \mathrm{N}$ longitude of $36^{\circ} 49^{\prime} \mathrm{E}$ ).

The samples were air-dried, thoroughly mixed, and passed through a $2 \mathrm{~mm}$ sieve. Some physicochemical properties of soil samples were measured. Soil texture was determined by the hydrometer method (22). The organic carbon (OC) content of the soil samples was determined by method of Walkley and Black (23), and the percentage of $\mathrm{CaCO} 3$ equivalent was measured using titration method (24). Also, soil pH and EC were measured in the saturated paste and saturated paste extract, respectively (25). Total porosity (TP) was obtained by the following equation (26):

$\% T P=1-\left(\frac{\rho_{b}}{\rho_{s}}\right) \times 100(3)$

Where $\rho_{b}$ is bulk density $\left(\mathrm{g} . \mathrm{cm}^{-3}\right)$ and $\rho_{s}$ is particle density $\left(\mathrm{g} . \mathrm{cm}^{-3}\right)$.

Using the sieving apparatus, the mean weight diameter (MWD) of aggregates was determined (27).

$M W D=\Sigma x i w i(4)$

Where $x i$ is the mean diameter of any particular size range of particles and wi is the weight of particles in that size range as a percentage of the total sample.

Moreover, wet aggregate stability (WAS) of aggregates was determined using sieving apparatus (27).

The physicochemical properties and the soils particle size distribution curve are shown in Table 2 and Figure 1.

Wind erosion experiment was performed in a wind tunnel $(0.8 \times 0.8 \times 16 \mathrm{~m})$ at velocities of $0-98 \mathrm{~km} \mathrm{~h}^{-1}$. The sample tray $(0.3 \times 0.5 \times 0.5 \mathrm{~m})$ used in this experiment, was placed

Table 1. Drought tolerance of isolates

\begin{tabular}{ll}
\hline$O D$ & Drought Tolerance \\
\hline$O D<0.3$ & Completely sensitive \\
$O D=0.3-0.5$ & Sensitive \\
$O D=0.5-0.7$ & Tolerant \\
$O D>0.7$ & Completely tolerant \\
\hline
\end{tabular}

OD, Optical density. on the floor, $8 \mathrm{~m}$ away from the entry of the wind tunnel (Figure 2).

The soil samples were treated with MICP using equimolar cementation solutions, including $1 \mathrm{M}$ urea and $1 \mathrm{M} \mathrm{CaCl}_{2}$, while two samples were treated with water served, and 1 $\mathrm{M}$ urea and $1 \mathrm{M} \mathrm{CaCl}_{2}$ as controls (Table 3).

For MICP processes, first, $400 \mathrm{~mL}$ bacterial suspension was sprayed on the soil surface with four replicates. After 24 hours, $400 \mathrm{~mL}$ cementation solution containing 200 $\mathrm{mL}$ urea and $200 \mathrm{~mL} \mathrm{CaCl}_{2}$ was sprayed on the soil surface with four replicates. The volume of MICP treatments including bacteria and cementation solutions to the trays was equivalent to $1 \mathrm{~cm}$ porosity from the depth of the samples. In other words, the volume of the solution was chosen in such a way that it could completely saturate 1 $\mathrm{cm}$ of top layer of the soil.

The treated samples were allowed to be air-dried for about ten days, and then, wind experiments were conducted.

The samples treated with MICP were exposed to different wind velocities for 5 minutes, and then, sediment flux ( $\mathrm{q}_{\mathrm{s}}$, $\mathrm{Kg} \mathrm{m}^{-2} \mathrm{~h}^{-1}$ ) was defined for each soil sample as the mass of soil $(\mathrm{g})$ transported from a surface unit $\left(\mathrm{m}^{2}\right)$ per time $(\mathrm{h})$ by the air flow. It was calculated as:

$q_{s}=\frac{m_{b}-m_{a}}{A . t}$

Where the total mass $(\mathrm{kg})$ of trays containing the soil before and after the experiment are $m_{b}$ and $m_{a}$, respectively. The area of trays is $A\left(\mathrm{~m}^{2}\right)$ and the run time is $t(\mathrm{~h})$.

Data analysis

Data were analyzed using SPSS version 16 software. Moreover, the scatter plots were prepared using Excel to find out the best relationship between soil erosion rate and the soil properties. Also, the significance of the obtained relationships was analyzed using regression analysis and F-test by SPSS version 16 .

Table 2. Physicochemical properties of the soils used in the experiment

\begin{tabular}{llll}
\hline Property & Unit & Soil 1 & Soil 2 \\
\hline Clay $(0-0.002 \mathrm{~mm})$ & $\%$ & 10 & 6 \\
Silt $(0.002-0.05 \mathrm{~mm})$ & $\%$ & 76 & 49 \\
Sand $(0.05-2 \mathrm{~mm})$ & $\%$ & 14 & 45 \\
Soil texture & - & Silt loam & Sandy loam \\
MWD & $\mathrm{mm}$ & 0.165 & 0.219 \\
Bulk density & $\mathrm{g} \mathrm{cm}^{-3}$ & 1.08 & 0.99 \\
WAS & - & 0.185 & 0.169 \\
OC & $\%$ & 0.08 & 0.07 \\
CCE & $\%$ & 11.32 & 8.99 \\
pH & - & 7.61 & 7.12 \\
EC & dSm-1 & 0.78 & 0.96 \\
TP & $\%$ & 62 & 54 \\
\hline
\end{tabular}

EC, electrical conductivity; TP, total porosity; CCE, calcium carbonate equivalent; OC, organic carbon; WAS, wet aggregate stability; MWD, Mean weight diameter. 


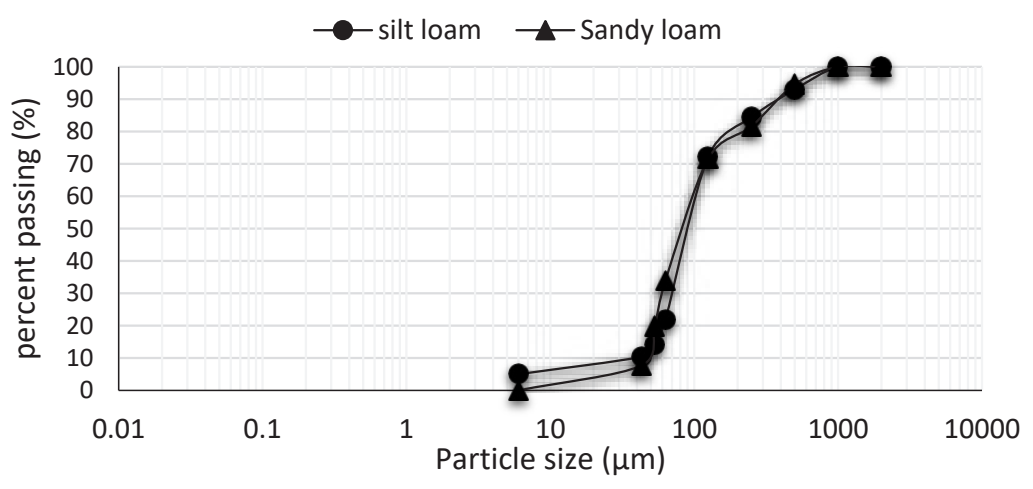

Figure 1. The soils particle size distribution curve.

\section{Results}

Isolation and identification of the strains of UPB

In this study, 130 different bacteria were isolated. The growth of UPB in enriched cultures from the soil samples was detected by the color change of the medium from light orange to crimson after 7 days of cultivation.

By quantitative testing, among 70 strains that were able to produce urease enzymes, strains with the highest amount of enzyme production were selected to determine the tolerance to drought stress test. Finally, 11 strains were selected and identified for wind tunnel experiment (Table 4).

Comparison of urease activity of the isolated strains The study showed that urease activity of the isolated strains was in the range of 5.62 to 36.84 hydrolyzed urea/

Table 3. Summary of the solutions used in this study

\begin{tabular}{lccc}
\hline Treatment & Solution & Volume (Pore volume) & Details \\
\hline \multirow{2}{*}{ MICP } & Bacterial & 0.5 & $\mathrm{MICP}_{1}-\mathrm{MICP}_{11}$ \\
& Urea & 0.25 & $1 \mathrm{M}$ urea \\
& $\mathrm{CaCl}_{2}$ & 0.25 & $1 \mathrm{M} \mathrm{CaCl}_{2}$ \\
\hline Control 1 & Water & 1 & - \\
\hline \multirow{2}{*}{ Control 2 } & Urea & 0.5 & $1 \mathrm{M} \mathrm{urea}$ \\
& $\mathrm{CaCl}_{2}$ & 0.5 & $1 \mathrm{M} \mathrm{CaCl}_{2}$ \\
\hline
\end{tabular}

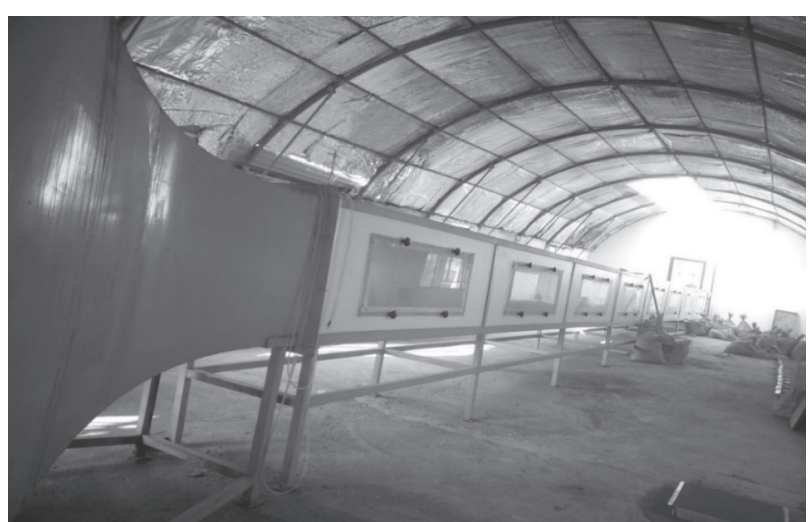

Figure 2. Wind tunnel used to perform wind erosion process.

min. Comparison of the results showed that Paenibacillus dendritiformis strain 14 and Bacillus megaterium strain 1 had maximum urease activity (Figure 3). Urease activity of the bacterial strains used in bio-cementation process in other studies was in the similar ranges. For example, Harkes et al (28) reported 5 to $20 \mathrm{mM}$ of hydrolyzed urea/ min for Sporosarcina pasteurii DSMZ 33. Also, for three Bacillus strains isolated from Australian soil and sludge, it was reported more than $3.3 \mathrm{mM}$ hydrolyzed urea/ $\min (29)$.

Table 4. Selected strains for wind tunnel experiment

\begin{tabular}{|c|c|c|c|}
\hline Treatment & Molecular Identification & Drought Tolerance & Urease Activity \\
\hline $\mathrm{MICP}_{1}$ & Chryseobacterium gleum strain 1 & Tolerant & + \\
\hline $\mathrm{MICP}_{2}$ & Bacillus halotolerans strain 12 & Tolerant & + \\
\hline $\mathrm{MICP}_{3}$ & Pseudomonas paralactis strain 10 & Tolerant & + \\
\hline $\mathrm{MICP}_{4}$ & Bacillus paralicheniformis strain 1 & Tolerant & + \\
\hline $\mathrm{MICP}_{5}$ & Paenibacillus dendritiformis strain1 & Tolerant & + \\
\hline $\mathrm{MICP}_{6}$ & Paenibacillus dendritiformis strain 2 & Tolerant & + \\
\hline $\mathrm{MICP}_{7}$ & Bacillus megaterium strain 1 & Tolerant & + \\
\hline $\mathrm{MICP}_{8}$ & Paenibacillus dendritiformis strain 14 & Completely tolerant & + \\
\hline $\mathrm{MICP}_{9}$ & Bacillus pumilus strain 9 & Tolerant & + \\
\hline $\mathrm{MICP}_{10}$ & Bacillus infantis strain 8 & Completely tolerant & + \\
\hline $\mathrm{MICP}_{11}$ & Bacillus albus strain 1 & Tolerant & + \\
\hline
\end{tabular}




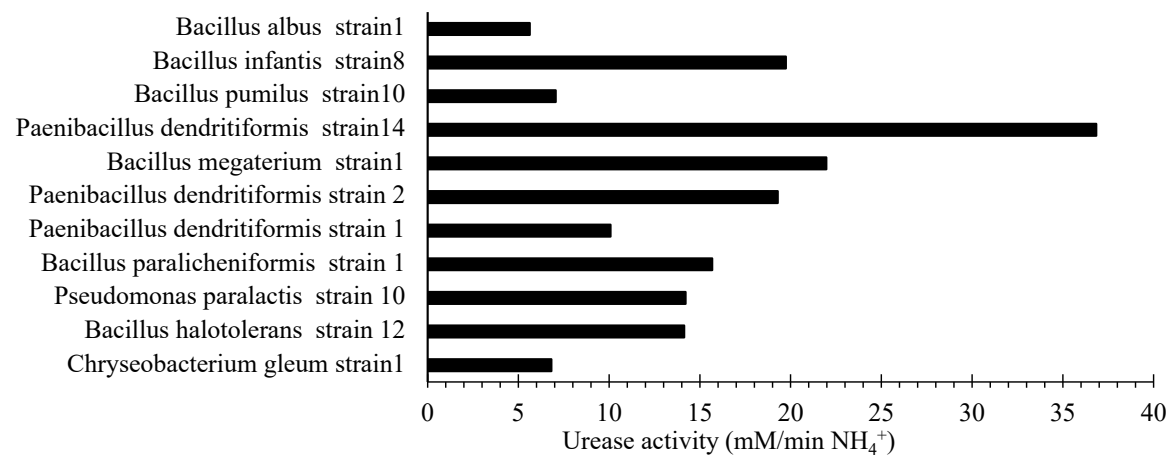

Figure 3. Comparison of urease activity of the isolated strains.

Effect of urease activity on the microbial-induced calcite precipitation

In order to evaluate the effect of urease activity on the amount of calcite precipitation, a direct investigation was carried out. The relationship between the measured calcite precipitation and urease activity is shown in Figure 4. As shown in this figure, there is a significant positive relationship between urease activity and the amount of calcite precipitation, and it follows on a power function basis $\left(\mathrm{R}^{2}=0.64, P<0.001\right)$.

In urea hydrolysis, urea reacts with water and produces the ionic product. When this reaction is performed in the presence of $\mathrm{Ca}^{2+}, \mathrm{CaCO} 3$ sediment is formed. Hydrolysis of urea is a slow and lengthy process when there is no catalyzer, but in the presence of urease enzyme, this reaction is about $10^{14}$ times faster than that of the natural process (30). In the presence of a urease-positive bacterium, urease enzyme is discharged from bacteria and the amount and rate of sediment formation are controlled by biological activity (31).

In the equal amounts of reactants (urea and calcium chloride), the higher amounts of urea hydrolysis occur when there is more urease activity in a specific time period. Therefore, in a specific time period, if reactants are continuously provided, more sediments are produced.

Effect of microbial-induced calcite precipitation on soil loss rate

The results of soil loss rate in MICP treatments and

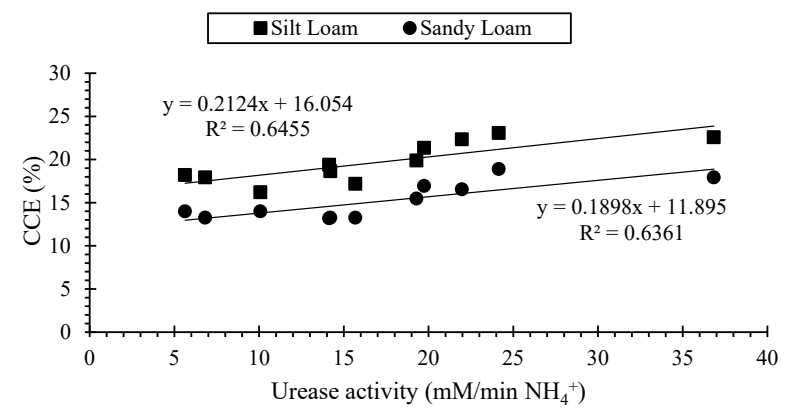

Figure 4. Relationship between calcium carbonate precipitation (\%) and urease activity $\left(\mathrm{mM} / \mathrm{min} \mathrm{NH}_{4}^{+}\right)$. control at different wind velocities are presented in Figure $5 \mathrm{a}$ and $\mathrm{b}$.

For wind tunnel experiments, the highest threshold wind speed measured on the disturbed soil was 8 and $10 \mathrm{~km}$ $\mathrm{h}^{-1}$ in silt loam and sandy loam, respectively. When winds reach a speed further than a threshold velocity, they are considered erosive (32).

In control samples, soil loss increased exponentially by increasing wind velocities. Up to $18 \mathrm{~km} \mathrm{~h}^{-1}$, soil erosion was not significant in both silty and sandy soils in control treatments. With increase of the wind velocity from 18 to $37 \mathrm{~km} \mathrm{~h}^{-1}$, the rate of soil loss increased from 15.2 to 89.8 $\mathrm{kg} \mathrm{m}^{-2} \mathrm{~h}^{-1}$ in silt loam. But in sandy loam at $57 \mathrm{~km} \mathrm{~h}^{-1}$, soil loss was significantly increased. This indicates that the velocity threshold of the particles in the silty soils is low and these particles are sensitive to erosion. By adding the solution of urea and calcium chloride, the soil loss rate of $37 \mathrm{~km} \mathrm{~h}^{-1}$ was not significant, but at higher velocities, soil loss rate was significant. Thus, by adding the cementation solutions, the dust release reduced but not so effectively as an aggregation of the fine sand. The results show that

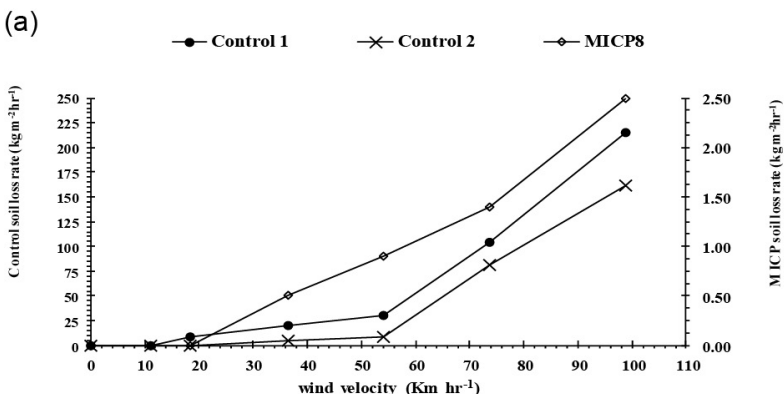

(b)

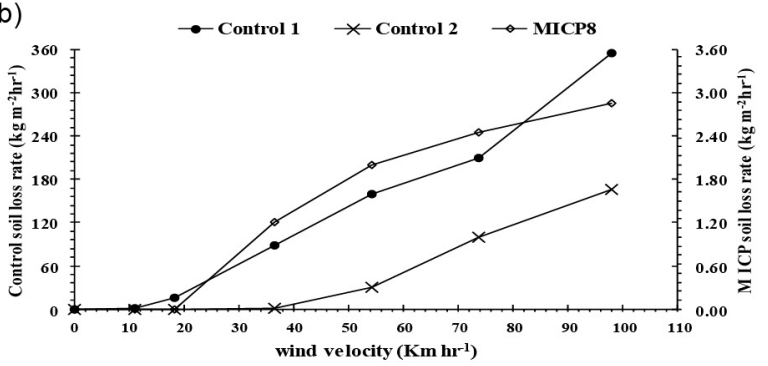

Figure 5. Soil loss rate $\left(\mathrm{kg} . \mathrm{m}^{-2} \cdot \mathrm{h}^{-1}\right)$ in sandy loam (a) and silty loam (b) at different velocities in MICP8 treatment. 
the addition of MICP increased soil resistance to erosion, and the best result is the addition of MICP8 to soil, as wind speed increases, the rate of soil loss from the MICP is very slow and increased at an average speed of $97 \mathrm{~km}$ $\mathrm{h}^{-1}$ to about $2.5 \mathrm{~kg} \mathrm{~m}^{-2} \mathrm{~h}^{-1}$. In addition, the difference in the amount of erosion between biological treatments and control is related to wind speed. Compared with MICP and control, at speed of $97 \mathrm{~km} \mathrm{~h}^{-1}$, the soil erosion mass for a control sample in sandy and silty soil was 215 and $354 \mathrm{~kg}$ $\mathrm{m}^{-2} \mathrm{~h}^{-1}$, respectively, while in $\mathrm{MICP}_{8}$ treatment, it was only about $2.50 \mathrm{~kg} \mathrm{~m}^{-2} \mathrm{~h}^{-1}$. This represents a very impressive effect of MICP in controlling wind erosion, especially at high wind speeds.

Wind is a major erosive force in arid and semi-arid regions where there is little vegetation coverage and organic matter to protect the soil surface. In sandy soil with application of MICP, calcite precipitation over the grain surfaces and around the grain contacts, creates a sandstone-like crust. In principle, MICP treatment protocols can be tailored to produce a more targeted deposition of calcite around the grain contacts (33) and thus, create bind between grains. Binding of soil particles can improve the soil structure and the agricultural properties of soils (11).

Effect of microbial-induced calcite precipitation on MWD Figure 6 shows the effect of MICP on MWD. The results of evaluation of the effect of MWD as an index of particle size distribution, on soil erodibility by wind show an inverse relationship between the MWD and the wind erosion rate. For high MWD values, the soil erosion decreased significantly, following a power function $\left(\mathrm{R}^{2}=0.67, \quad P<0.001\right)$.

Effect of microbial-induced calcite precipitation on porosity

These results suggest that the presence of $\mathrm{CaCO} 3$ had a clear effect on the porosity of the material, and a reasonable relationship between the two parameters was observed. A reduction in the pore volume was caused by the precipitation of $\mathrm{CaCO} 3$ in the pore spaces.

The greater reduction in porosity was seen in the treatment with higher content of the precipitated calcium which was decreased to $30 \%$ in the untreated samples. The linear relationship between porosity and content of the precipitated calcium is shown in Figure 7. Eryuruk et al reported that this reduction occurs through $\mathrm{CaCO} 3$ precipitation by bacterial activity (34). Also, Whiffin et al, investigated the MICP as a technique for soil improvement and observed that the column porosity at the maximum $\mathrm{CaCO} 3$ content was decreased to $90 \%$ of the untreated material (35).

\section{Discussion}

One of the methods of soil improvement is microbialinduced $\mathrm{CaCO} 3$ precipitation (MICP), when $\mathrm{CaCO} 3$ crystal is produced between soil particles by bacteria. In MICP process, when $\mathrm{CaCO} 3$ precipitates inside soil particle or porous material, after settling the produced

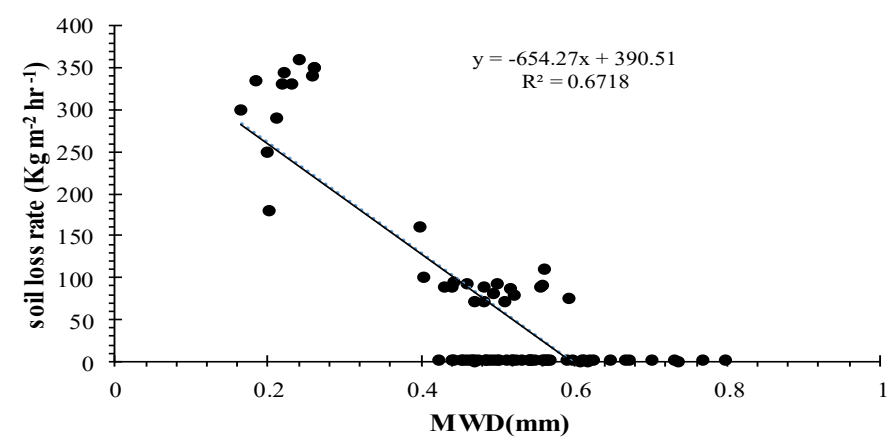

Figure 6. Effect of the mean weight diameter (MWD) of soil particles on the soil erosion by wind.

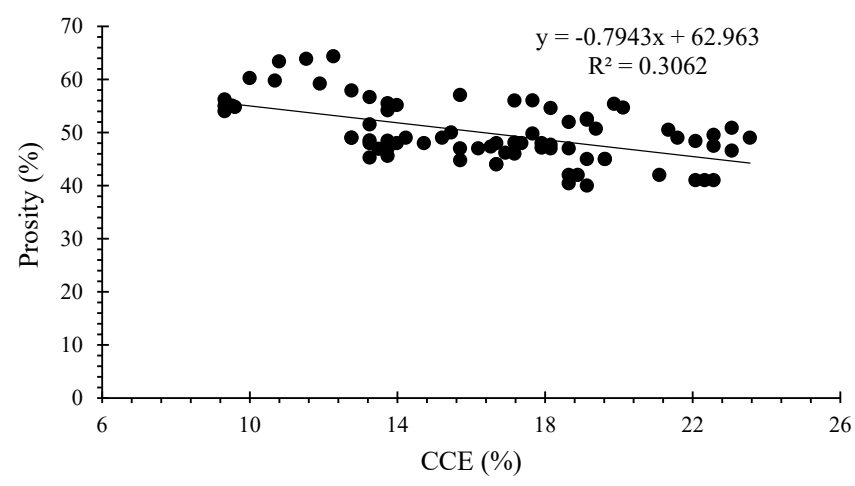

Figure 7. Relationships between the total porosity of soil and calcite precipitation (CCE). 
sediment, $\mathrm{CaCO} 3$ acts as a cementing and coating agent, and the bridge is formed around and between the particles. With increase of the linkage between particles, this procedure can stabilize the soil or porous material and result in increased aggregation and stability (36).

According to the results of this study, there is a relationship between the calcite precipitation (CCE) and the wind erosion rate (Figure 8). The soil erosion rate decreases significantly for high CCE values. Then, the rate of soil loss for the soil modified by bacteria was improved through the deposition of the new calcite material by the bacterial activity.

Comparing the soil erosion mass in a control sample with MICP at speed of $97 \mathrm{~km} \mathrm{~h}^{-1}$, showed that the amount of soil loss in sandy and silty soil was 215 and $354 \mathrm{~kg} \mathrm{~m}^{-2}$ $\mathrm{h}^{-1}$, respectively, while for the $\mathrm{MICP}_{8}$ treatment, it was only about $2.50 \mathrm{~kg} \mathrm{~m}^{-2} \mathrm{~h}^{-1}$. This represents a very impressive effect of MICP in controlling wind erosion, especially at high wind speeds. In addition, the results of this study indicate that MWD of soil particles is strongly related to $\mathrm{CaCO} 3$ precipitation content $\left(\mathrm{R}^{2}=0.67, P<0.001\right)$ (Figure 9). Other studies reported a lower rate of soil erodibility with increasing the MWD of soil particles $(37,38)$.

Maleki et al investigated the effect of MICP on the rate of soil loss and showed that for low and high bacterial concentrations, the rate of soil loss for the treated samples and control treatment was 1.29 and $0.16 \%$, respectively, indicating a considerable improvement in erosion control in the biologically-treated samples (17). Also, Douzali Joushin et al studied the inhibition of wind erosion by
SBR polymer and Bacillus pasteurii microorganism in Jabal Kandy region (Isfahan province) and observed that with increasing the wind speed, the amount of soil erosion increases exponentially, so that in the control sample, up to $7 \mathrm{~m} \mathrm{~s}^{-1}$, the amount of soil erosion is negligible, but by increasing the velocity rate from 5.51 to $240 \mathrm{~kg} \cdot \mathrm{m}^{-2} \mathrm{~h}^{-1}$, soil erosion also increased from about $7 \mathrm{~m} \mathrm{~s}^{-1}$ to about $15 \mathrm{~m} \mathrm{~s}^{-1}$. Also, they reported that the trend of increasing the amount of soil erosion in a sample stabilized by microorganisms was very slow and at a speed of $15 \mathrm{~m} \mathrm{~s}^{-1}$, it was equal to 1.1 $\mathrm{kg} \mathrm{m}^{-2} \mathrm{~h}^{-1}(39)$.

\section{Conclusion}

This paper presents the results of a laboratory investigation on MICP for wind erosion control in sandy and silty soils. Soil samples were subject to different MICP treatments to monitor the erosional responses when wind erosion was taking place. According to the results, there is a significant positive relationship between urease activity and the amount of calcite precipitation. Thus, in the equal amounts of reactants (urea and calcium chloride), the case which has more urease activity, more amount of urea is hydrolyzed in a specific time period and higher amounts of calcite precipitation occur. The results indicated that the application of MICP on soil surface can be an effective alternative for the wind erosion control, especially at higher velocities.

The effectiveness of MICP for erosion control was mainly dominated by the amount of carbonate precipitation, MICP8 with high ability in producing urease enzyme is

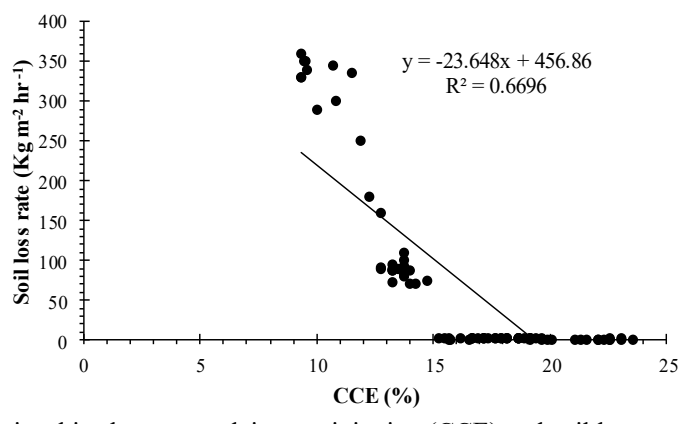

Figure 8. Relationships between calcite precipitation (CCE) and soil loss rate $\left(\mathrm{kg} \cdot \mathrm{m}^{-2} \cdot \mathrm{h}^{-1}\right)$.

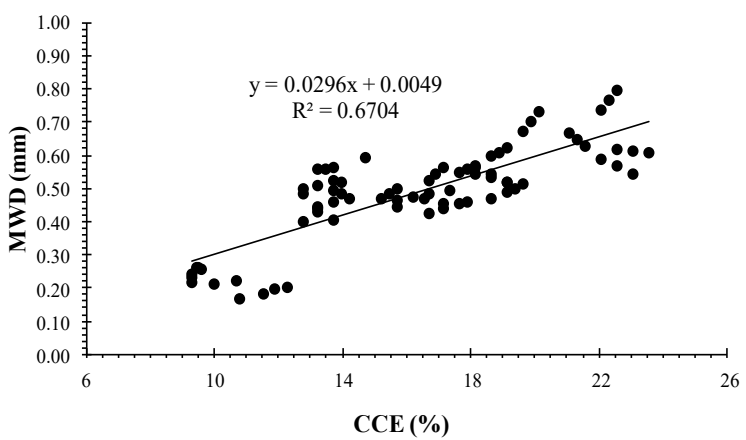

Figure 9. Relationships between the mean weight diameter (MWD) of soil particles and calcite precipitation. 
able to produce increased levels of precipitated carbonate, which corresponds to reduced fines loss.

MWD, as an index of particle size distribution, has a significant effect on the resistance of surface against wind erosion. There is a strong relationship between the amount of soil loss and MWD in the biologically-treated samples, indicating that the formation of the aggregate structure by MICP process could remarkably reduce the amount of erosion and provide sand dune stabilization for dust control and future revegetation.

\section{Acknowledgments}

This study was extracted from a Ph.D. thesis, which was conducted at the Soil and Water Research Institute, Karaj, and Forestry and Rangeland Research Institute, Tehran. The authors would like to gratitude Gorgan University of Agricultural Sciences and Natural Resources for financial support and all people who contributed in improving the study.

\section{Ethical issues}

The author certifies that all data collected during the study are as described in the manuscript and no information from this study will be published elsewhere separately.

\section{Competing interests}

The authors declared that they have no competing interests.

\section{Authors' contributions}

All authors contributed in the suggestion of the problem, design of experiments, data collection, analysis, and interpretation, and the manuscript approval.

\section{References}

1. Santra P, Moharana PC, Kumar M, Soni ML, Pandey CB, Chaudhari SK, et al. Crop production and economic loss due to wind erosion in hot arid ecosystem of India. Aeolian Research 2017; 28: 71-82. doi: 10.1016/j.aeolia.2017.07.009.

2. Saadoud D, Hassani M, Martin Peinado FJ, Guettouche MS. Application of fuzzy logic approach for wind erosion hazard mapping in Laghouat region (Algeria) using remote sensing and GIS. Aeolian Research 2018; 32: 24-34. doi: 10.1016/j.aeolia.2018.01.002.

3. Chappell A, Webb NP, Guerschman JP, Thomas DT, Mata G, Handcock RN, et al. Improving ground cover monitoring for wind erosion assessment using MODIS BRDF parameters. Remote Sens Environ 2018; 204: 756-68. doi: $\quad 10.1016 /$ j.rse.2017.09.026.

4. Zhang C, Wang X, Zou X, Tian J, Liu B, Li J, et al. Estimation of surface shear strength of undisturbed soils in the eastern part of northern China's wind erosion area. Soil and Tillage Research 2018; 178: 1-10. doi: 10.1016/j.still.2017.12.014.

5. Sterk G, Parigiani J, Cittadini E, Peters P, Scholberg JM, Peri PL. Aeolian sediment mass fluxes on a sandy soil in Central Patagonia. Catena 2012; 95: 112-23. doi: 10.1016/j. catena.2012.02.005.
6. Zou XY, Zhang C, Cheng H, Kang L, Wu YO. Cogitation on developing a dynamic model of soil wind erosion. Sci China Earth Sci 2015; 58(3): 462-73. doi: 10.1007/s11430014-5002-5.

7. Fattah MY, Joni HH, Al-Dulaimy AS. Strength characteristics of dune sand stabilized with lime-silica fume mix. International Journal of Pavement Engineering 2018; 19(10): 874-82. doi: 10.1080/10298436.2016.1215687.

8. Goodrich BA, Jacobi WR. Foliar damage, ion content, and mortality rate of five common roadside tree species treated with soil applications of magnesium chloride. Water Air Soil Pollut 2012; 223(2): 847-62. doi: 10.1007/s11270-0110907-5.

9. Han Z, Wang T, Dong Z, Hu Y, Yao Z. Chemical stabilization of mobile dunefields along a highway in the Taklimakan Desert of China. J Arid Environ 2007; 68(2): 260-70. doi: 10.1016/j.jaridenv.2006.05.007.

10. Tisdall JM, Nelson SE, Wilkinson KG, Smith SE, McKenzie BM. Stabilisation of soil against wind erosion by six saprotrophic fungi. Soil Biol Biochem 2012; 50: 134-41. doi: 10.1016/j.soilbio.2012.02.035.

11. Zhang YM, Wang HL, Wang XQ, Yang WK, Zhang DY. The microstructure of microbiotic crust and its influence on wind erosion for a sandy soil surface in the Gurbantunggut Desert of Northwestern China. Geoderma 2006; 132(3-4): 441-9. doi: 10.1016/j.geoderma.2005.06.008.

12. Stabnikov V, Chu J, Myo AN, Ivanov V. Immobilization of sand dust and associated pollutants using bioaggregation. Water Air Soil Pollut 2013; 224(9): 1631. doi: 10.1007/ s11270-013-1631-0.

13. Bang S, Min SH, Bang SS. Application of microbiologically induced soil stabilization technique for dust suppression. International Journal of Geo-Engineering 2011; 3(2): 27-37.

14. Dejong JT, Soga K, Kavazanjian E, Burns S, Van Paassen LA, Al Qabany A, et al. Biogeochemical processes and geotechnical applications: progress, opportunities and challenges. Geotechnique 2013; 63(4): 287-301. doi: 10.1680/geot.SIP13.P.017.

15. Ivanov $\mathrm{V}$, Chu J. Applications of microorganisms to geotechnical engineering for bioclogging and biocementation of soil in situ. Reviews in Environmental Science and Bio/Technology 2008; 7(2): 139-53. doi: 10.1007/s11157-007-9126-3.

16. Chu J, Ivanov V, Naeimi M, Stabnikov V, Liu HL. Optimization of calcium-based bioclogging and biocementation of sand. Acta Geotech 2014; 9(2): 277-85. doi: 10.1007/s11440-013-0278-8.

17. Maleki M, Ebrahimi S, Asadzadeh F, Emami Tabrizi M. Performance of microbial-induced carbonate precipitation on wind erosion control of sandy soil. Int J Environ Sci Technol 2016; 13(3): 937-44. doi: 10.1007/s13762-0150921-z.

18. Gomez MG, Anderson CM, Dejong JT, Nelson DC, Lau XH. Stimulating in situ soil bacteria for bio-cementation of sands. Geotechnical Special Publication. 2(234):1674-82.

19. Kim D, Park K. An environmentally friendly soil improvement technologywith microorganism. International Journal of Railway 2013; 6(3):90-4.doi: 10.7782/IJR.2013.6.3.090

20. Burbank MB, Weaver TJ, Williams BC, Crawford RL. Urease activity of ureolytic bacteria isolated from six 
soils in which calcite was precipitated by indigenous bacteria. Geomicrobiol J 2012; 29(4): 389-95. doi: 10.1080/01490451.2011.575913.

21. Michel BE, Kaufmann MR. The osmotic potential of polyethylene glycol 6000. Plant Physiol 1973; 51(5): 914-6. doi: 10.1104/pp.51.5.914.

22. Gee GW, Or D. Particle size analysis. In: Dane JH, Topp GC, eds. Methods of Soil Analysis. Part 4. Physical Methods. USA: Soil Science Society of America; 2002.

23. Walkley A, Black IA. An examination of the Degtjareff method for determining soil organic matter, and a proposed modification of the chromic acid titration method. Soil Sci 1934; 37(1): 29-38. doi: 10.1097/00010694-19340100000003.

24. Pansu M, Gautheyrou J. Handbook of Soil Analysis: Mineralogical, Organic and Inorganic Methods. Berlin: Springer Science and Business Media; 2006.

25. Page AL, Miller RH, Jeeney DR. Methods of Soil Analysis, Part 2. Chemical and Mineralogical Properties. USA: Soil Science Society of America; 1992.

26. Sasal MC, Andriulo AE, Taboada MA. Soil porosity characteristics and water movement under zero tillage in silty soils in Argentinian Pampas. Soil and Tillage Research 2006; 87(1): 9-18. doi: 10.1016/j.still.2005.02.025.

27. Kemper WD, Rosenau RC. Aggregate stability and size distribution. In: Klute A, ed. Methods of Soil Analysis. Madison (WI): American Statistical Association, Soil Science Society of America; 1986.

28. Harkes MP, Van Paassen LA, Booster JL, Whiffin VS, Van Loosdrecht MC. Fixation and distribution of bacterial activity in sand to induce carbonate precipitation for ground reinforcement. Ecol Eng 2010; 36(2): 112-7. doi: 10.1016/j.ecoleng.2009.01.004.

29. Al-Thawadi S, Cord-Ruwisch R, Bououdina M. Consolidation of sand particles by nanoparticles of calcite after concentrating ureolytic bacteria in situ. Int J Green Nanotechnol 2012; 4(1): 28-36. doi: $10.1080 / 19430892.2012 .654741$

30. Kalantary F, Kahani M. Evaluation of the Ability to Control Biological Precipitation to Improve Sandy Soils. Procedia Earth and Planetary Science 2015; 15: 278-84. doi: 10.1016/j.proeps.2015.08.067.

31. Kahani M. Experimental investigation on parameters affecting biocementation of sandy soils [dissertation]. Tehran: K. N. Toosi University of Technology; 2012. [In Persian].

32. Zobeck TM, Van Pelt RS. Wind Erosion. In: Hatfield JL, Sauer TJ. Soil Management: Building a Stable Base for Agriculture. Madison, Wisconsin: American Society of Agronomy, Soil Science Society of America; 2011. doi: 10.2136/2011.soilmanagement.c14.

33. Viganotti M. Biogrout Pore scale bonding phenomena in saturated and unsaturated soils [dissertation]. Dublin: The University of Dublin; 2014.

34. Eryuruk K, Yang S, Suzuki D, Sakaguchi I, Akatsuka T, Tsuchiya $\mathrm{T}$, et al. Reducing hydraulic conductivity of porous media using $\mathrm{CaCO}(3)$ precipitation induced by Sporosarcina pasteurii. J Biosci Bioeng 2015; 119(3): 331-6. doi: $\quad 10.1016 /$ j.jbiosc.2014.08.009.

35. Whiffin VS, Van Paassen LV, Harkes MP. Microbial carbonate precipitation as a soil improvement technique. Geomicrobiol J 2007; 24(5): 417-23. doi: $10.1080 / 01490450701436505$.

36. Achal V, Mukherjee A. A review of microbial precipitation for sustainable construction. Constr Build Mater 2015; 93: 1224-35. doi: 10.1016/j.conbuildmat.2015.04.051.

37. Kheirabadi $H$, Mahmoodabadi $M$, Jalali V, Naghavi $H$. Sediment flux, wind erosion and net erosion influenced by soil bed length, wind velocity and aggregate size distribution. Geoderma 2018; 323: 22-30. doi: 10.1016/j. geoderma.2018.02.042

38. Sirjani E, Sameni A, Moosavi AA, Mahmoodabadi M, Laurent B. Portable wind tunnel experiments to study soil erosion by wind and its link to soil properties in the Fars province, Iran. Geoderma 2019; 333: 69-80. doi: 10.1016/j. geoderma.2018.07.012.

39. Douzali Joushin F, Badv K, Barin M, Sultani Jige $H$. Inhibition of wind erosion by SBR polymer and Bacillus pasteurii microorganism (Case study: Jabal Kandy region). Iranian Journal of Soil and Water Research 2018; 49(4): 795806. doi: 10.22059/ijswr.2018.237063.667721. [In Persian]. 